РОЛЬ ІНТЕРАКТИВУ ЯК ГРУПОВОЇ ВЗАЄМОДІЇ

У ФОРМУВАННІ ЧИТАЦЬКИХ КОМПЕТЕНТНОСТЕЙ УЧНІВ

НА УРОКАХ УКРАЇНСЬКОÏ ЛІТЕРАТУРИ

\title{
THE ROLE OF INTERACT AS A GROUP COLLABORATION IN THE FORMATION OF PUPILS' READING COMPETENCES AT THE LESSONS OF UKRAINIAN LITERATURE
}

У статті аналізується роль інтерактивних і групових методів, прийомів, технологій на уроках української літератури як таких, що максимально забезпечують діалогічну взаємодію школярів, сприяють організації необхідного співробітничтва і взаємонавчання під час вивчення художніх творів, спонукають учнів до дискусії, спілкування, діалогу. Автором статті обгрунтовується необхідність фрормування у школярів предметних, загальнонавчальних, життєво необхідних компетентностей, зокрема читацьких компетентностей, а також формування учня-читача, який розуміє чіннісне значення читання для власного успішного становлення у житті, здатен працювати у команді, спілкуватися, взаємодіяти, вести діалог, критично мислити, прагнути до навчання упродовж життя. Автор статті наголошує на необхідності максимального використання інтерактиву як групової взаємодії, що забезпечує суб'єктність усіх учасників освіт ньої діяльності; допомагає активізувати та вмотивувати певний процес навчання; спонукає учнів до вироблення власного ставлення до проблеми, висловлення особистої думки, розуміння альтернативних поглядів і вироблення умінь приймати зважені рішення. Акцентується увага на тому, що фрормування в учнів необхідних компетентностей має відбуватися в єдиній системі використання різноманітних прийомів, методів, дій, операцій, технологій, де діалогічні, групові та інтерактивні методи організації освітньої діяльності учнів стають пріоритетними. Працюючи в парах, групах, ротаційних трійках, школярі навчаються брати на себе відповідальність і добросовісно виконувати доручену роль; ухвалювати спільні рішення, почуваючись членом спільноти; усвідомлювати важливість власної ініціативності, небайдужості, активності у визначенні громадянської позиції. Автор статmі звертає увагу учителів-практиків на необхідність забезпечення компетентнісного підходу до навчання, використання сучасного методичного інструментарію, в основу якого покладені групові та інтерактивні методи роботи, а також прийоми критичного мислення, які сприяють налагодженню комунікації учнів із автором і героями художнього твору з метою пошуку особистісних смислів у виучуваному.
Ключові слова: українська література, читацькі компетентності, учень-читач, інтерактив, робота у групах, діалогічна взаємодія, художній твір.

The article analyzes the role of interactive and group methods, techniques and technologies at the lessons of Ukrainian literature as those that maximize the dialogic interaction of students, facilitate the organization of necessary cooperation and mutual learning, encourage students to discuss, communicate and conduct a dialogue during the study of works of fiction. The author of the article substantiates students' need to develop subject, general and vital competencies, including reading competences, as well as the formation of a student-reader who understands the value of reading for successful development in life, is able to work in a team, communicate, engage in a dialogue, think critically and strive for lifelong learning. The author emphasizes the necessity of maximizing the use of interactive as group interaction, providing the subjectivity of all participants of educational activities; helping to activate and motivate certain learning process encouraging students to develop their own attitude to the problem, express personal opinions, understand alternative perspectives and develop reasoned decision-making skills. Emphasis is placed on the fact that the formation of the necessary students' competences should occur in a single system of using various techniques, methods, actions, operations and technologies, prioritizing dialogic, group and interactive methods of educational activities organization. Working in pairs, groups, rotary groups of three, students learn to take responsibility and conscientiously perform their assigned roles; make joint decisions, feel themselves being members of the community; realize the importance of their own initiative, indifference and activity in determining their civic position. The author draws attention of teachers-practitioners to the necessity of competent approach in learning and use of modern methodological tools, which are based on group and interactive methods, as well as critical thinking techniques, that facilitate communication between students, the author and characters of the work of fiction in order to search for personal meanings in the subject.

Key words: Ukrainian literature, reading competences, student-reader, interactive, group work, dialogic interaction, work of fiction.

Дніпропетровської обласної ради

Постановка проблеми в загальному вигляді. Сьогодні ми визнаємо, що освіта донедавна була закритою сферою, але нині світ настільки стрімко глобалізується, що і в освіті не може не відбуватися кардинальних змін. Безумовно, зважаючи на технічний прогрес, школа потребує модернізації, матеріально-технічного й навчально-методичного оновлення, перегляду питання реального фрінан- сування тощо. Та найважливішим кроком для нас, педагогів, є модернізація змісту освіти, що ґрунтується на компетентнісному, особистісно зорієнтованому та діяльнісному підходах до навчання й орієнтує на здобуття учнями умінь і навичок, необхідних сучасній людині для успішної самореалізації у профеесійній діяльності, особистому житті, громадській активності. 
У цьогорічних методичних рекомендаціях Міністерства освіти і науки України щодо викладання навчальних предметів у закладах загальної середньої освіти у 2019/2020 навчальному році особлива увага звертається на те, що у змісті навчальних програм послідовно впроваджено компетентнісний підхід, який відповідає стратегічному напряму розвитку освіти в контексті положень Концепції «Нова українська школа» [2, с. 2].

Оновлені програми 3 української літератури для загальноосвітніх навчальних закладів спрямовують викладачів на розвиток і соціалізацію учнів, формування у них національної самосвідомості, навичок практичного використання досвіду, здобутого за допомогою читання, усвідомлення важливості читання як чинника власного становлення й соціалізації, а підібрані твори дають можливість школярам пережити насолоду від прочитаного, допомагають дітям у практично-ігровій формі підготуватися до життя, поміркувати над учинками персонажів, подискутувати з приводу моральних і світоглядних колізій, наявних у художньому світі, спробувати вирішити важливі соціальні проблеми, визначити власні цінності й орієнтири [3, с. 3-4]. Саме «Українська література» як навчальний предмет має значний потенціал для фрормування на уроках літератури компетентного учня-читача, здатного до діалогічної взаємодії, відкритого до комунікації з ровесниками, спроможного зрозуміти цінність читання для самореалізації та саморозвитку, що особливо важливо в епоху потужного розвитку інорормаційних технологій.

Аналіз останніх досліджень і публікацій. У Концепції реалізації державної політики у сфрері рефрормування загальної середньої освіти «Нова українська школа» зазначається, що «найбільш успішними на ринку праці в найближчій перспективі будуть фрахівці, які вміють навчатися упродовж життя, критично мислити, ставити цілі та досягати їх, працювати в команді, спілкуватися в багатокультурному середовищі та володіють іншими уміннями» $[1$, с. 3]. Тобто метою Нової української школи є виховання інноватора та громадянина, котрий умітиме ухвалювати відповідальні рішення, розв'язувати необхідні проблеми, опираючись на морально-етичні принципи та набуті знання, уміння, навички, компетентності, а саме: уміння читати і розуміти прочитане, готовність висловлювати думку і критично мислити, здатність логічно обґрунтовувати позицію, виявляти ініціативу, творити, співпрацювати в команді тощо.

У Концепції передбачено і реформування педагогіки загальної середньої освіти шляхом переходу до педагогіки партнерства між учнем і учителем, що потребує ґрунтовної підготовки учителів за новими методиками і технологіями навчання. Відомо, що у шкільній практиці у певні історичні періоди переважали різні фрорми організації навчальної діяльності. Історично першим і широко розповсюдженим було індивідуальне навчання. Йому на зміну згодом прийшло індивідуально-групове, потім - колективне (фрронтальне). У сучасній школі практикуються різні організаційні форми навчання і продовжуються пошуки нових педагогічних технологій.

Інноваційні технології сучасної шкільної освіти, які передбачають широке використання групових форм роботи, досліджуються М.О. Алексєєвим, С.П. Бондар, М.В. Кларіним, О.М. Пєхотою, І.П. Підласим, О.І. Пометун, С.І. Подмазіним, Г.С. Сазоненко та іншими вченими. Так, О.І. Пометун слушно зазначає, що групові технології приваблюють практиків суб'єкт-суб'єктною взаємодією на уроках, бо це істотно змінює і роль педагога. Під час групової роботи учитель спрямовує, координує діяльність учнів, які самостійно працюють над навчальними завданнями, допомагає організувати дослідження, проконтролює в разі потреби найскладніші етапи роботи груп. Колективний розум у співробітництві здатний вирішити багато проблем швидше й ефективніше. Відбувається обмін знаннями та ідеями, коли кожен працює на кожного. Змінюється навіть психологічна атмосфера, тому в групі і «слабкі» учні не комплексують, беруть активну участь у розв'язанні проблем, самі вибудовують свою фрормулу успіху [4, с. 47-48].

Питання організації групової діяльності школярів на уроках літератури відображені у роботах учених-методистів Н.Й. Волошиної, О.С. Жили, О.О. Ісаєвої, Л.Ф. Мірошниченко, Г.Л. Токмань, А.М. Фасолі. Слушними є рекомендації А.М. Фасолі щодо системного впровадження групових методів роботи, які забезпечують діяльнісну основу уроку, та інтерактивних технологій, що сприяють «виробленню компетентностей, оскільки під час застосування інтерактивного навчання переважає самостійна діяльність і взаємонавчання» [5, с. 21]. Список запропонованих ученим прийомів, які будуть доречними на уроках літератури і які сьогодні активно використовуються педагогами, достатньо місткий: «Мікрофрон», взаємне навчання, «Займи позицію» та «Кутки», технологія ПРЕС, «Два - чотири - всі разом», «Мозаїка», «Акваріум», «Діаграма Вена», ґронування, кубування, обмін проблемами та ін.

Найголовніше те, що всі учені одностайно стверджують: навчання у групах сприяє розвитку комунікативних здібностей школярів, а постійне спілкування формує уміння обирати шляхи, щоб досягти найбільшого взаєморозуміння. З'являється можливість обговорення групою змісту завдань і способів їх виконання. Учні спільно аналізують проблеми, оцінюють пропозиції, радяться, дискутують один 3 одним. Кожен член групи має можливість проговорити матеріал уголос, висловити свою думку, учні звикають вислуховувати, не переби- 
ваючи, один одного, що дуже важливо для сучасних дітей. Це дисциплінує, розвиває логічне мислення, спонукає до активної розумової діяльності, привчає до культури мовлення. Якраз у вільному спілкуванні у малій групі найповніше розкриваються індивідуальні здібності учнів, реалізуються їхні пізнавальні можливості, фрормується нове ставлення до навчання. Однак багато актуальних питань саме щодо організації групової навчальної діяльності на уроках української літератури залишаються нез'ясованими і потребують практичного наповнення.

Мета статті - зосередити увагу всіх, хто причетний до шкільної літературної освіти, на необхідності фрормування на уроках літератури компетентного учня-читача, відкритого до комунікації з ровесниками, зацікавленого у результатах свого навчання, здатного до діалогічної взаємодії з автором твору, літературними героями, текстом художнього твору, спроможного зрозуміти цінність читання для самореалізації, а отже, спроможного до навчання і саморозвитку упродовж життя.

Виклад основного матеріалу. У статті йтиметься про предметні (читацькі) компетентності учнів, які фрормуються на уроках літератури, зокрема української. Як уже відомо, компетентність - це інтегрована здатність учня, що складається зі знань, умінь, досвіду, цінностей і ставлення, які можуть цілісно реалізовуватися на практиці. Що ж до читацької компетентності, то скористаємося ґрунтовним трактуванням цієї десрініції ученим-методистом А.М. Фасолею: «Читацька компетентність - це якість особистості, що виявляється в готовності та здатності самостійно здобувати і застосовувати пов'язані з читацькою діяльністю знання та вміння розв'язувати актуальні завдання, здійснювати читацький і особистісний саморозвиток» [6, с. 2].

Роль літературної освіти для сучасного покоління важко переоцінити. В умовах тотальної глобалізації вкрай важливо зберегти свою, українську неповторність і не асимілюватися. А саме українська література є потужним носієм ідентичності нації, її генетичного коду, тому в національному самоусвідомленні, самозбереженні та самоствердженні іï роль незаперечна і важлива. Потоки сучасної інфрормації 3 мас-медіа та соціальних мереж змінюють психологію читання і читача, здійснюють становлення світоглядних позицій цілих поколінь XXI ст. За цих умов особливо важливе те, що читає дитина і як вона сприймає прочитане, чи вміє критично проаналізувати твір мистецтва слова та розставити особистісні акценти. 3 огляду на це читацька компетентність стає ключовою, необхідною людині на різних етапах життя у різноманітних сорерах життєдіяльності.

Педагоги Дніпропетровщини усвідомлюють важливість оновлення методичного інструмента- рію відповідно до вимог сьогодення, тому дедалі частіше зосереджують увагу на групових фрормах та інтерактивних технологіях, які забезпечують партнерство учителя й учня на уроці, дозволяють розкрити творчі здібності й нахили учнів, створюють сприятливі умови для розвитку та самореалізації школярів і фрормування у них необхідних компетентностей. У системі післядипломної педагогічної освіти ми систематично працюємо над методикою організації групової та інтерактивної взаємодії на уроках літератури. Методика групового, інтерактивного навчання (3 англійської «interact», де «inter» - взаємний і «act» - діяти, тобто інтерактивний - здатний до взаємодії, діалогу), як і будь-якої педагогічної технології, вимагає від учителя високого рівня розуміння необхідності інноваційного оновлення навчального процесу, усвідомлення того, що сьогодні педагог не може бути абсолютним носієм інформації. Саме тому він повинен свідомо сприймати необхідність психологічної переорієнтації, оскільки його відносини з учнями набувають характеру спілкування, переходять у площину співпраці, взаємодії. Для організації навчання учнів у групах необхідна активна позиція учителя, його готовність до інноваційних фрункцій: бути на уроці організатором, координатором, порадником, партнером, котрий супроводжує процес самопізнання, забезпечує учневі позицію справжнього суб'єкта навчання. Принциповим моментом для вчителя має бути створення на уроці плідної атмосфери спілкування, вироблення навичок критичного мислення та природного прагнення кожної дитини до самовираження, що максимально реалізується під час групової діяльності школярів. Обов'язковою умовою впровадження групової фрорми діяльності $€$ підготовка учнів до взаємонавчання, співробітництва, спілкування, бо учні мають знати, як поводитися з партнерами, виконувати функціональні обов'язки, приймати спільні рішення, доповідати від імені групи тощо. Працюючи у групі, школярі вчаться коментувати головні ідеї твору, стиль письменника, явища мистецтва; висловлювати судження (дискутувати) з приводу проблем, порушених у творі, їхньої актуальності $з$ позицій сьогодення; творчо використовувати додаткові джерела інформації, довідники, енциклопедії, Інтернет.

Групова навчальна діяльність школярів може бути організована практично на уроці будь-якого типу та на кожному 3 його етапів. Це може бути як епізодичне введення групової роботи до структури уроку (тривалістю 8-15 хвилин), так і довготривала діяльність (30-40 хвилин). Головне, що групова форма діяльності спонукає школярів до активної участі в освітньому процесі, до ініціативності та самостійності. Під час вивчення біограсрії письменника найчастіше і найбільш успішно учні працюють у рольових групах: «біографи», 
«історики», «літературні критики», «фрілософри», «дослідники», «краєзнавці», «мистецтвознавці» тощо. Саме творчі групові завдання спонукають учнів до пошуків інфрормації, фрормують інтелект, сприяють розширенню світогляду, забезпечують ситуацію успіху, бо в кінці уроку визначається найкращий «біографр», найцікавіший «критик», найталановитіший читець. Пріоритетність таких творчих груп пояснюється специорікою: вони мобільні, утворюються здебільшого за бажанням учнів, не вимагають багато часу на фрормування. Школярі самостійно розподіляють обов'язки, розшукують матеріал, аналізують його і вибирають найнеобхіднішу інформацію для кількахвилинного повідомлення. Вони виступають активними організаторами й учасниками навчального процесу, реалізуючи комунікативні уміння в конкретній ситуації, готуючи власні повідомлення та презентації, критично переосмислюючи увесь матеріал.

Під час роботи над змістом художнього твору доречно організовувати за бажанням школярів тематичні групи: творчі, артистичні, дослідницькі, проблемні, експертні, діалогічні, аналітичні, пошукові тощо. Наприклад, для того, щоб семикласники зробити висновок, що головна героїня вірша Ліни Костенко «Кольорові миші» наділена багатою уявою, франтазією і талантом, учні працювали у творчих групах, обравши свою емблему і колір; складали асоціативні кущі; описували вигляд героїні, якою вони її уявляли; озвучували власні твори-мініатюри «Мій кольоровий сон» і «Моя мрія»; навіть складали кольоровий букет для Анни. Найцікавішою була дискусія між перехресними групами з приводу вирішення проблемного питання: «А чи легко бути не таким, як усі?» Учням було що сказати з цього питання (для декого воно було доволі болючим), тому спілкування 3 ровесниками допомогло вирішити особистісні проблеми. Насамкінець учням пропонувалося написати лист-пораду одному з персонажів, зберігши інтригу в тому, що лист треба писати від імені «кота, що нявкнув» (теж одного із суб'єктів твору). На перший погляд може скластися враження, що на одному уроці занадто велике навантаження на учнів, але коли ти бачиш, що байдужих серед них немає, кожен намагається якнайшвидше впоратися із завданням, донести до однокласників своє розуміння ситуації, допомогти головній героїні залишатися індивідуальністю з незвичайним баченням навколишнього світу, то розумієш, що саме такі комунікативно-діяльнісні уроки, на яких учні усвідомлюють високі моральні якості людини, є цікавими, важливими, результативними.

Працюючи з одинадцятикласниками над змістом поезій Богдана-Ігоря Антонича «Різдво» і «Коляда», варто звернутися до інтерактивної вправи «Діаграма Вена». Учні в парах досліджу- ють спільні та відмінні ознаки в поезіях, порівнюють поезії з біблійною легендою про народження Христа, вирішують проблемні питання щодо паралельного використання поетом язичницьких і християнських елементів. Таким чином, школярі занурюються у серйозні життєві питання, оволодівають соціальною взаємодією, навчаються критично мислити, самовдосконалюватися і налагоджувати гармонійні стосунки з ровесниками. Окрім читацьких, у школярів фрормуються соціальні, комунікативні, креативні компетентності. Наступна групова робота над змістом поезії Б.-І. Антонича «Дороги» розкриває можливості та індивідуальні здібності кожного з учасників: перша група (літературознавці) працює над аналізом поезії, відповідаючи на запитання: «Символом чого в поезії $€$ дорога?», «Якою постає природа в поезії?», «У чому ви вбачаєте оригінальність поезії?». друга група (митці) виписує з поезії слухові, зорові та інші образи, а третя група «письменників» складає пам'ятки для своїх ровесників, котрі скоро вирушать у доросле життя, на тему: «Що потрібно брати 3 собою, вирушаючи в «дорогу»? Учасники груп презентують свою роботу, із зацікавленням слухають розмірковування своїх однокласників, роблять для себе життєво важливий висновок: «Дороги - це наше життя, треба пройти їх так, щоб не схибити». Результатом подальшого уже реорлексійного інтерактиву буде «Сенкан» до теми «Антонич». Наприклад: 1) Антонич. 2) Неповторний, оригінальний. 3) Любив, дивував і дивувався. 4) Краса природи в слові ожила. 5) Поет. Тож, організовуючи роботу над змістом твору, педагог особливо ретельно добирає інтерактивні методи, які б сприяли розвитку уяви та навичок критичного мислення учнів, спонукали до вироблення власного ставлення до проблеми і висловлення особистої думки, забезпечували порівняння альтернативних поглядів і вироблення умінь приймати зважені колективні рішення.

Узагальнюючи сказане, зазначимо, що групова навчальна діяльність сприяє творчому засвоєнню знань, полегшує управління пізнавальною роботою учнів, створює позитивний емоційний фон, допомагає аналізувати проблемні ситуації. Групова робота на уроці забезпечує покращення психологічного клімату, оптимізує взаємини учителя й учня, а також учня з учнем. Ця форма роботи не дозволяє залишатися пасивним у навчальному процесі, байдужим до завдань, до інших членів групи, а навпаки, стимулює до дискусії, співробітництва, взаємодопомоги, взаєморозуміння. Під час виконання завдань у групі створюються можливості для активної діяльності кожного учня, більш глибокого та свідомого засвоєння матеріалу, розвитку творчих та організаційних здібностей, фрормування комунікативних навичок, необхідних для спілкування. Інтерактивні заняття 
дають змогу дітям у групі розв'язувати складні проблеми, позбуваючись звичної ролі споглядача і споживача в освітньому процесі. Дійсно, інтеракція виключає домінування як будь-якого учасника навчання, так і будь-якої думки над іншими. У процесі діалогічного навчання учні вчаться критично мислити, розв'язувати складні проблеми на основі аналізу обставин і відповідної інформації, зважувати альтернативні думки, приймати продумані рішення, брати участь у дискусії, спілкуватися 3 іншими людьми. Важливо, що успіх кожного члена групи залежить як від його особистих зусиль, так і від внеску його товаришів.

Висновки. Отже, суть групового (інтерактивного) навчання полягає в тому, що практично кожен учень $є$ активним учасником, суб'єктом процесу пізнання, який відбувається у комунікативній взаємодії, в атмосорері доброзичливості та взаємної підтримки. Оскільки на уроках літератури відкриваються великі можливості для створення атмосфери вільного спілкування і невимушеності співпраці, то учитель, готуючись до уроку, повинен не тільки акцентувати увагу на найцікавіших моментах сюжету художнього твору та найактуальніших проблемах, а й дібрати такі види роботи, щоб учні стали активними учасниками і творцями уроку. Учителям-срілологам необхідно вибудовувати уроки на засадах діалогічності, інтерсуб'єктного навчання, співробітництва, щоб зацікавити учнів емоційно-ціннісною взаємодією 3 автором-оповідачем і героями твору; сприяти конструктивному діалогу з ровесниками; спонукати до критичного мислення, оригінального вирішення проблем у процесі спілкування, до саморозкриття та самоутвердження.

\section{БІБЛІОГРАФІЧНИЙ СПИСОК:}

1. Концепція реалізації державної політики у сорері ресрормування загальної середньої освіти «Нова українська школа» на період до 2029 року (Схвалено розпорядженням Кабінету Міністрів України від 14 грудня 2016 р. № 988-p). URL: https://osvita.ua/legislation/Ser_osv/54258 (дата звернення: 30.07.2019).

2. Методичні рекомендації про викладання навчальних предметів у закладах загальної середньої освіти у 2019/2020 навчальному році. Лист MOH України № 1/11-5966 від 01 липня 2019 р. URL: https://nus.org.ua/news/mon-rozrobylo-metodychnirekomendatsiyi-z-vykladannya-predmetiv-na2019-2020/ (дата звернення: 30.07.2019).

3. Українськалітература.5-9класи.Програмадля загальноосвітніх навчальних закладів, затверджена наказом МОН України від 07 червня 2017 р. № 804. URL: https://imzo.gov.ua/osvita/zagalno-serednyaosvita-2/navchalni-prohramy-5-9-klasy-naskriznizmistovi-liniji/ukrainska-literatura-naskrizni-zmistoviliniji/ (дата звернення: 18.03.2019).

4. Пометун О.І. Технологія інтерактивного навчання як інноваційне педагогічне явище. Рідна школа. 2007. № 5. С. 46-49.

5. Фасоля А.М. Інтерактивне навчання на уроках української літератури у 5-7 класах: системність і систематичність. Українська мова і література у школі. 2007. № 6. С. 20-24

6. Фасоля А.М. Читацька компетентність: що формуємо, що і як перевіряємо й оцінюємо. Дивослово. 2017. № 9. C. 1-8. URL: https://dyvoslovo.com.ua/ wp-content/uploads/2017/0 (дата звернення: 31.07.2019). 